\title{
APLIKASI RAJUTAN BAMBU SEBAGAI TULANGAN BALOK BETON
}

\section{Application of Knitted Bamboo For Concrete Reinforcement Beams}

\author{
Agostinho Francisco Pintor ${ }^{1}$, Sri Murni Dewi², Devi Nurlinah ${ }^{3}$ \\ 1,2,3 Jurusan Teknik Sipil Fakultas Teknik Universitas Brawijaya Malang \\ JL. MT. Haryono No. 167 Malang, 65145, Jawa Timur \\ Email : frehd_ko@yahoo.com
}

\begin{abstract}
Need for the use of reinforced concrete in housing construction will increase along with the rapid population growth. This increases the need for steel reinforcement as a major component. The increase in need for steel reinforcement will trigger a price increase so that it becomes expensive and scarce. Iron ore as a raw material for making steel reinforcement is a mineral that can not be renewed. Therefore, efforts to use alternatives to steel reinforcement in concrete. Bamboo has good mechanical properties and a high ratio between strength and weight. Bamboo has a tensile strength is high, between 100-400 MPa, nearly matching the tensile strength equivalent to steel reinforcement $1 / 2$ to $1 / 4$ of iron ultimate voltage showed similar results andthat the tensile strength of bamboo can reach $1280 \mathrm{~kg} / \mathrm{cm}^{2}$. Bamboo can be used as the material of reinforced concrete. This study aims to determine the capacity of the bending beam with reinforcement of bamboo, bamboo reinforced beam deflection capacity. This experiment is a concrete beam bending test. The results showed that bamboo reinforced concrete beam has a maximum capacity reached $56.61 \%$ of the maximum capacity of steel reinforced concrete.
\end{abstract}

Keywords: Bamboo, flexural capacity, deflection.

\begin{abstract}
Abstrak
Kebutuhan penggunaan beton bertulang dalam pembangunan perumahan akan semakin meningkat seiring dengan semakin pesatnya pertumbuhan penduduk. Hal ini menningkatkan kebutuhan tulangan baja sebagai komponen utama. Kenaikan kebutuhan tulangan baja akan memicu kenaikan harga sehingga menjadi mahal dan langka. Bijih besi sebagai bahan baku pembuatan tulangan baja merupakan mineral yang tidak dapat diperbaharui. Oleh karena itu, perlu upaya menggunakan alternatif pengganti tulangan baja pada beton. Bambu memiliki sifat mekanik yang baik dan rasio yang tinggi antara kekuatan dan berat. Bambu mempunyai kekuatan tarik yang cukup tinggi, antara 100-400 Mpa, hampir menyamai kekuatan tarik besi tulangan setara dengan $1 / 2$ sampai $1 / 4$ dari tegangan ultimate besi menunjukkan hasil yang sama dan kuat tarik bambu dapat mencapai $1280 \mathrm{~kg} / \mathrm{cm}^{2}$. Bambu dapat digunakan sebagai material beton bertulang. Penelitian ini bertujuan untuk mengetahui kapasitas lentur balok dengan tulangan bambu, kapasitas lendutan balok bertulang bambu. Pengujian yang dilakukan adalah uji lentur balok beton. Hasil penelitian menunjukan bahwa balok beton bertulang bambu memiliki kapasitas maksimum mencapai 56,61\% dari kapasitas maksimum beton bertulang baja.
\end{abstract}

Kata Kunci : Bambu, kapasitas lentur, lendutan.

\section{PENDAHULUAN}

Pelaksanaan pembangunan infrastruktur waktu demi waktu semakin meningkat, sesuai dengan pemenuh kebutuhan dari semua aspek kehidupan. Pelaksanaan pembangunan tersebut tidak terlepas juga dengan inovasi terhadap semua aspek pendukung dalam pembangunan tersebut. Beton merupakan salah satu bentuk aspek utama dalam pembangunan infrastruktur baik itu gedung, jembatan, jalan, dll. Beton sederhana dibentuk oleh pengerasan campuran semen, air, agregat halus, agregat kasar (batu pecah atau kerikil), udara, dan kadang-kadang campuran tambahan lainnya (Nawy, 2010).

Beton mempunyai nilai kuat tekan relatif lebih tinggi dibandingkan dengan kuat tariknya.Kuat tekan beton umur 28 hari berkisar antara nilai lebih kurang 10-65 
Mpa.Nilai kuat tarik beton hanya berkisar 9\% sampai 15\% dari kuat tekannya (Mulyono, 2004). Penambahan tulangan pada beton difungsikan untuk menahan gaya tarik yang memikul beban-beban yang bekerja pada beton tersebut. Daerah tekan pada balok juga dapat diperkuat dengan penggunaan tulangan ini.Sehingga beton tersebut tidak hanya berdiri sendiri, yang mana disebut juga dengan beton bertulang.

Semakin mahalnya harga tulangan baja ini akan sangat memberatkan bagi masyarakat terutama masyarakat golongan ekonomi lemah, dalam upaya mereka untuk memenuhi kebutuhan primernya, yaitu berupa perumahan yang layak huni. Oleh sebab itulah perlu diupayakan mencari alternatif baru pengganti tulangan baja pada beton. Adapun alternatif lain sebagai pengganti tulangan beton tersebut, diantaranya adalah bambu. Bambu merupakan produk hasil alam yang renewable yang dapat diperoleh dengan mudah, murah, mudah ditanam, pertumbuhan cepat, dapat mereduksi efek global warming serta memiliki kuat tarik tinggi (Setiyabudi, 2010).

Bambu dapat digunakan sebagai tulangan beton pengganti baja karena mempunyai kekuatan tarik tinggi yang mendekati kekuatan baja. Seperti yang dikemukakan oleh Morisco (1999), bahwa pemilihan bambu sebagai bahan bangunan dapat didasarkan seperti pada harga yang relatif rendah, pertumbuhan cepat, mudah ditanam, mudah dikerjakan, serta keunggulan spesifik yaitu serat bamboomemiliki sifat mekanik yang baik dan rasio yang tinggi antara kekuatan dan berat. Bambu mempunyai kekuatan tarik yang cukup tinggi, antara 100-400 Mpa, hampir menyamai kekuatan tarik besi tulangan setara dengan $1 / 2$ sampai $1 / 4$ dari tegangan ultimate besi (Widjaja, 2001) serta (Surjokusumo dan Nugroho, 1993) menunjukkan hasil yang sama dan menurut Morisco, 1996 bahwa kuat tarikbambu dapat mencapai $1280 \mathrm{~kg} / \mathrm{cm}^{2}$.

\section{Beberapa Penelitian yang Pernah Dilakukan Pada Balok Beton Bambu}

Hakim (1987), berdasarkan hasil penelitiannya menyatakan bahwa jenis bambu belah dengan nodia berpengaruh sangat nyata terhadap kekuatan tarik maksimum bambu belah tanpa nodia, sedangkan posisi contoh benda uji tidak berpengaruh secara nyata, rata- rata kekuatan tarik terendah terdapat pada bambu Apus 2558,46 kg/cm2, bambuWulung $2833,4784 \mathrm{~kg} / \mathrm{cm} 2$, bambu Legi 2835,141 $\mathrm{kg} / \mathrm{cm} 2$, bambu Ori $3062,703 \mathrm{~kg} / \mathrm{cm} 2$, bambu Ampel 3229,014kg/cm2, dan bambu Petung $3958,2324 \mathrm{~kg} / \mathrm{cm} 2$.

Penelitian Morisco (1999), memperlihatkan kekuatan tarik bambu dapat mencapai sekitar dua kali kekuatan tarikbaja tulangan. Sebagai pembanding dipakai baja tulangan beton dengan tegangan leleh sekitar $240 \mathrm{MPa}$ yangmewakili baja beton yang banyak terdapat di pasaran. Dari penelitian diperoleh bahwa kuat tarik kulit bambu Ori cukup tinggi yaitu hampir mencapai $500 \mathrm{MPa}$, sedang kuat tarik rata-rata bambu Petung juga lebih tinggi daritegangan leleh baja, hanya satu spesimen yang mempunyai kuat tarik lebih rendah dari tegangan leleh baja.

\section{METODE PENELITIAN}

Penelitian ini merupakan metode experimental laboratorium. Penelitian ini dilakukan di laboratorium Struktur dan Bahan Konstruksi Jurusan Teknik Sipil Universitas Brawijaya.

Bambu yang digunakan sebagai tulangan akan dirajut dengan cara bambu di belah terlebih dahulu dengan ukuran kecil setelah itu bambu belahan dirajut menjadi bambu rajutan untuk tulangan beton.

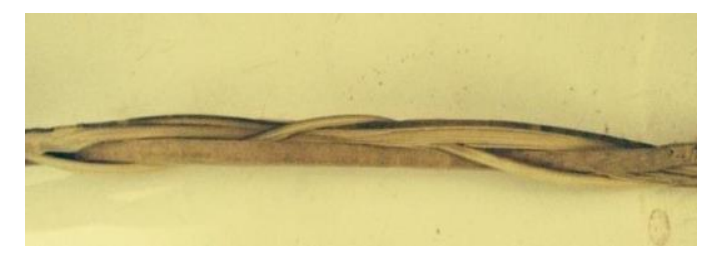

Gambar 1. Rajutan bambu

Benda uji berupa balok beton dengan tulangan (reinforced concrete) dengan ukuran $15 \times 25 \times 170 \mathrm{~cm}$. Balok tersebut diletakkan pada dua tumpuan yang dibebani dengan beban dua beban statik yang terukur pada bentang balok tersebut. Detail benda uji dapat dilihat pada gambar di bawah ini. 
Tabel 1. Klasifikasi Rasio Penulangan

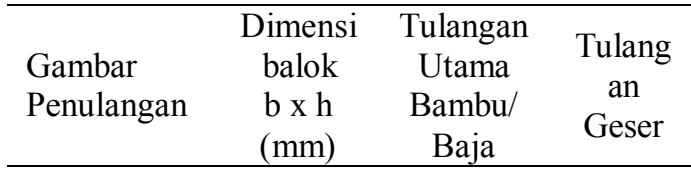

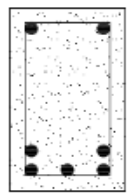

Tul.

Bambu

$5 \mathrm{D} 12$

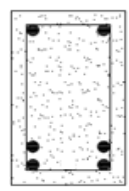

$\begin{array}{cc} & \text { Tul. } \\ 150 & \text { Bambu } \\ \times 250 & 4 \text { D12 }\end{array}$

$\phi 8-$

4 D12
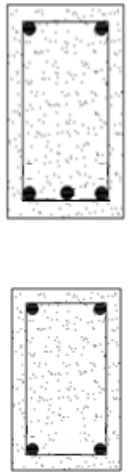

150

x 250

Tul.

Tul.

Bambu

3 D12

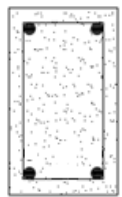

Tul. Baja

150

x 250

2 D12

$\phi 8-$

150

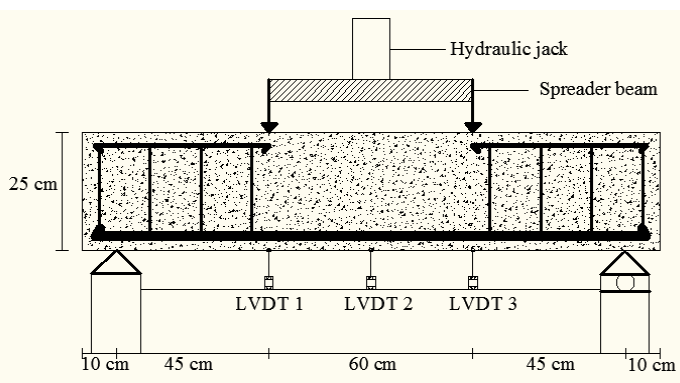

Gambar 2. Skema rangkaian pembebanan dan pengujian

Benda uji dibuat menggunakan beton yang sebelumnya telah dibuat mix design-nya. Setelah benda uji mencapai umur 28 hari kemudian diadakan pengujian dan pengambilan data berupa pengambilan beban statik, dan lendutan.

\section{HASIL DAN PEMBAHASAN}

\section{Pengujian kuat tekanBeton}

Delapan buah benda uji beton selinder di uji pada umur 28 hari untuk mendapatan nilai kuat tekan beton. Berdasarkan hasil pengujian didapatkan Nilai kuat tekan beton adalah 20 MPa.

\section{Hasil pengujian Lentur balok}

Pengujian lentur pada balok merupakan pengujian yang dilakukan dengan meletakkan balok pada dua tumpuan sederhana, kemudian di beri dua beban garis pada jarak yang telah ditentukan. Lendutan balok di peroleh dari pembacaan LVDTyang diletakan di tengah bentang dan tepat di bawah salah satu beban garis yang di berikan pada balok, seperti yang di tunjukan pada oleh Gambar 3.

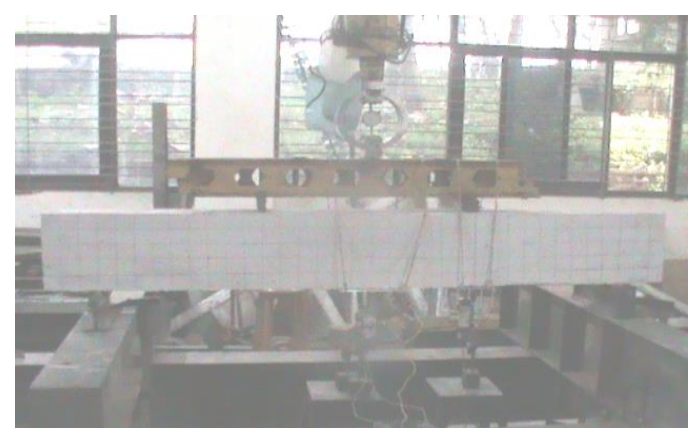

Gambar 3. Pengujian lentur balok

Tabel 2. Beban maksimum rata-rata pada Balok Beton.

\begin{tabular}{lcc}
\hline Benda Uji Balok & $\begin{array}{c}\text { P max } \\
(\mathrm{Kg})\end{array}$ & $\begin{array}{c}\text { Lendutan Max } \\
(\mathrm{mm})\end{array}$ \\
\hline Rata-rata BK & 8067 & 29,01 \\
Rata-rata BB 2 & 4567 & 18,2 \\
Rata-rata BB 3 & 5517 & 17,65 \\
Rata-rata BB 4 & 6367 & 19,10 \\
Rata-rata BB 5 & 7342 & 20,61 \\
\hline
\end{tabular}

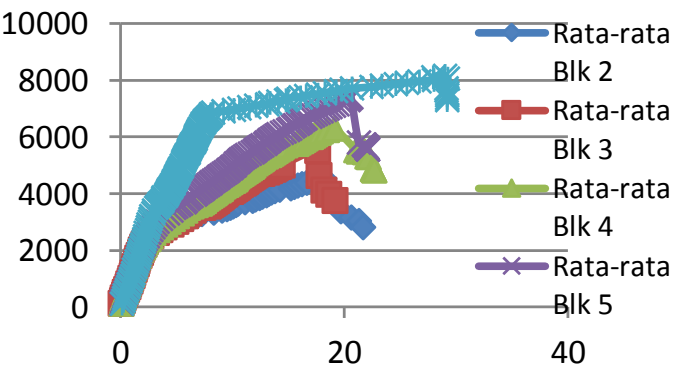

Gambar 4. Grafik Hubungan Beban dengan Lendutan Rata-rata Balok 


\section{Hasil pengujian Lendutan balok}

Tabel. 3. Lendutan dengan Beban yang sama $4567 \mathrm{Kg}$ pada balok beton bertulang bambu

\begin{tabular}{ccc}
\hline Benda Uji Balok & $\mathrm{P}(\mathrm{Kg})$ & $\begin{array}{c}\text { Lendutan } \\
\text { Max (mm) }\end{array}$ \\
\hline Rata-rata BB 2 & 4567 & 18,2 \\
Rata-rata BB 3 & 4567 & 11,6 \\
Rata-rata BB 4 & 4567 & 10,3 \\
Rata-rata BB 5 & 4567 & 8,6 \\
\hline
\end{tabular}

Dari hasil Tabel 3 dapat kita lihat nilai lendutan dengan beban $4567 \mathrm{~kg}$ pada balok beton bertulang bambu. penambahan jumlah tulangan bambu pada balok beton bertulang bambu di daerah tarik menghasilkan nilai lendutan menjadi berkurang dengan beban yang sama.

\section{Teoritis}

Analisis Lentur balok beton yang digunakan pada peneltitian ini mengacu pada anlisis secara kovensional balok beton. keseimbangan antara gaya tekan pada beton (C) dengan gaya tarik pada tulangan ( $\mathrm{T}$ ) harus terpenuhi. Gaya tarik pada tulangan $(\mathrm{T})$ yaitu hasil hasil perkalian luas tulangan dengan nilai kuat tarik pada tulangan, dan nilai (C) diperoleh dari perkalian luas daerah tekan beton dengan kuat tekan beton. Perhitungan Beban maksimum yang diperoleh pada balok beton dengan berbagai variasi tulangan bambu di sajikan dalam tabel berikut.

Tabel 4. Beban teoritis maksimum pada Balok Beton.

\begin{tabular}{cc}
\hline Benda Uji Balok & P max ( Kg) \\
\hline BK & 5279,36 \\
BB 2 & 2870,65 \\
BB 3 & 4123,77 \\
BB 4 & 4989,73 \\
BB 5 & 5687,90 \\
\hline
\end{tabular}

\section{Perbandingan Beban maksimum antara Hasil Eksperimen denganTeoritis}

Bedasarkan hasil secara teoritis,maka dapat dibandingkan hasil hasil beban maksimum dan lendutan maksimum yang diperoleh secara teoritis dengan beban maksimum dan lendutan maksimum yang diperoleh dari eksperimen. Perbandingan hasil beban maksimum ditunjukan oleh Gambar 5 .

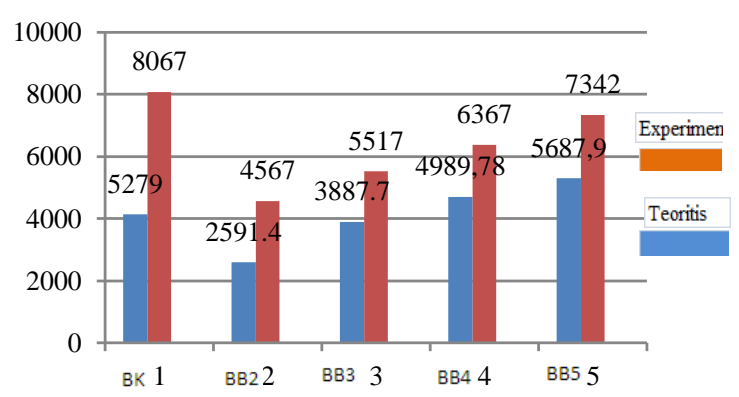

Gambar 5. Diagram Perbandingan Beban Maksimum Balok Beton .

\section{Pola Retak}

Berdasarkan pengujian yang telah dilakukan, dapat diamati pola retak yang terjadi pada balok beton dengan dua tumpuan sederhana dengan berbagai macam variasi tulangan. Pada benda uji balok beton bertulang baja, retak yang terjadi adalah retak akibat lentur yang terjadi di tengah bentang dimana berawal dari retak rambut yang terjadi di tengah bentang sehingga retak tersebut membesar dan mengakibatkan runtuh. Pola keruntuhan balok beton bertulang baja dapat di lihat pada Gambar 6.

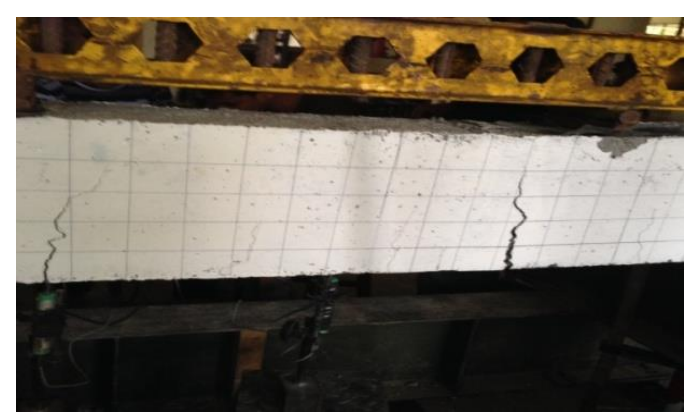

Gambar 6. Pola keruntuhan balok beton bertulang baja

Pada dasarnya pola retak yang terjadi pada benda uji balok beton bertulang bambu dengan berbagai variasi jumlah tulangan mempunyai pola retak keruntuhan yang sama dengan balok beton bertulang baja, dimana retak yang terjadi adalah retak akibat lentur yang terjadi di tengah bentang. . Pola keruntuhan balok beton bertulang baja dapat di lihat pada Gambar 7, Gambar 8, Gambar 9 dan Gambar 10. 


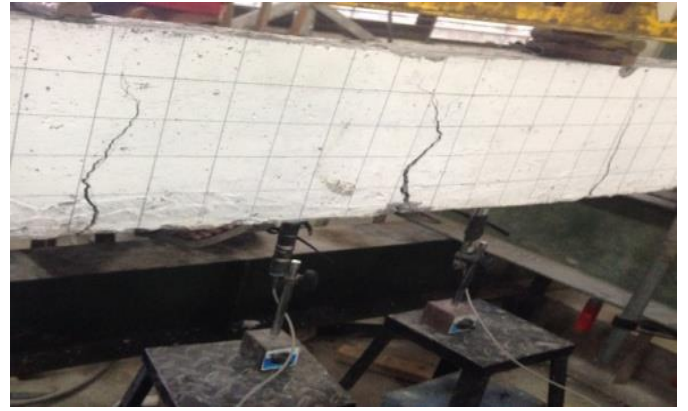

Gambar 7. Pola keruntuhan balok beton bertulang bambu 2D12

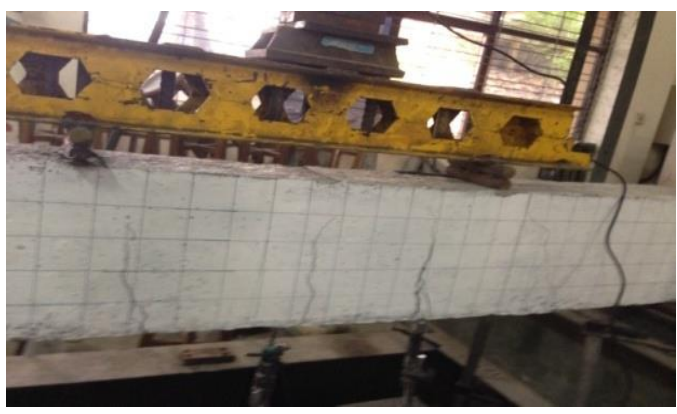

Gambar. 8. Pola keruntuhan balok beton bertulang bambu 3D12

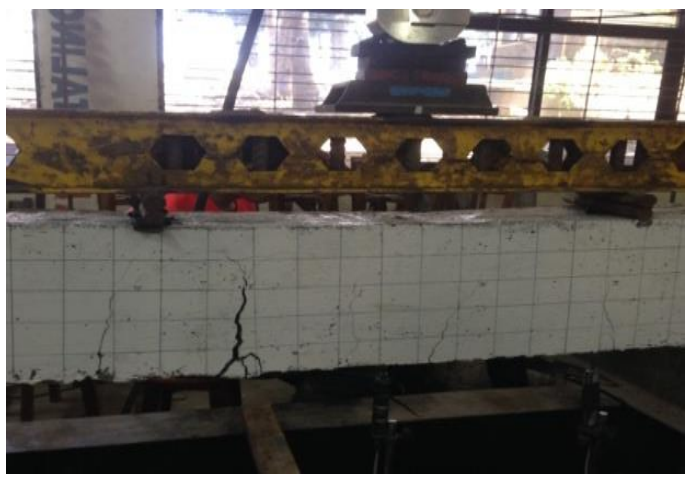

Gambar. 9. Pola keruntuhan balok beton bertulang bambu 4D12

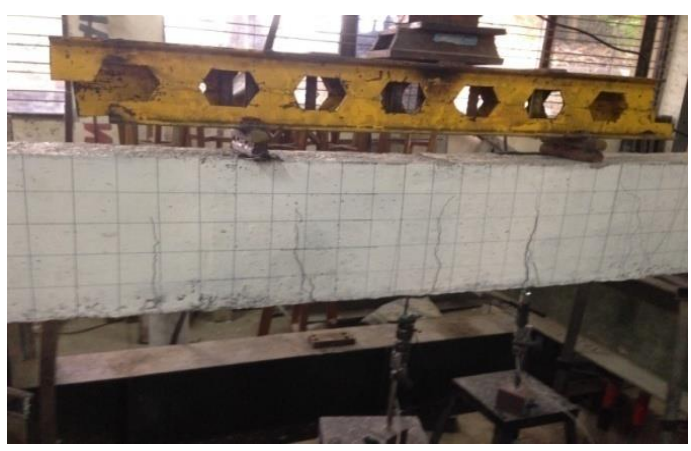

Gambar. 10 Pola keruntuhan balok beton bertulang bambu $5 \mathrm{D} 12$

\section{Uji Hipotesis}

Suatu pengujian hipotesis statistic ialah prosedur yang dapat digunakan untuk menarik suatu kesimpulan atau kepututsan untuk menolak atau menerima hipotesis yang sedang diuji.

Untuk menguji hipotesis, digunakan data yang dikumpulkan dari sampel, sehingga merupakan data prakiraan, itulah sebabnya, keputusan yang dibuat di dalam menolak atau menerima hipotesis mengandung ke tidak pastian, maksudnya keputusan bisa benar atau bisa juga salah. Adanya unsur ketidak pastian menyebabkan timbulnya resiko dalam pembuatan keputusan. Besar kecilnya resiko dinyatakan dalam nilai probabilitas.

Pengujian hipotesis variasi jumlah tulangan bambu terhadap kapasitas beban maksimum balok beton bertulang bambu.

Pengujian hipotesis dalam penelitian ini dilakukan untuk mengetahui apakah ada pengaruh penambahan jumlah tulangan bambu terhadap kapasitas beban maksimum balok beton bertulang bambu.

$\mathrm{H} 0$ = tidak terdapat pengaruh yang signifikan antara penambahan jumlah tulangan terhadap kapasitas beban maksimumbalok beton.

$\mathrm{H} 1$ = terdapat pengaruh yang signifikan antara penambahan jumlah tulangan terhadap kapasitas beban maksimumbalok beton.

Level of signifikan $(a)=5 \%=0,05$

$\mathrm{F}(\alpha ; \mathrm{k}-1 ; \mathrm{k}(\mathrm{n}-1))=\mathrm{F}(0,05 ; 3 ; 4)=$ Ftabel $=$ 6,59

$\mathrm{H0}$ : diterima apabila $\mathrm{F} \leq 6,59$

$\mathrm{H} 1$ : ditolak apabila $\mathrm{F} \geq 6,59$

Karena nilai Fhitung > Ftabel ( 26,662 > 6,59 ), maka H0 di tolak. Sehingga terdapat pengaruh yang signifikan antara penambahan rasio tulangan bambu terhadap beban maksimum balok beton bertulang bambu.

\section{Pengujian hipotesis variasi jumlah tulangan bambu terhadap kapasitas lendutan balok beton bertulang bambu.}

Pengujian hipotesis dalam penelitian ini dilakukan untuk mengetahui apakah ada 
pengaruh penambahan jumlah tulangan bambu terhadap kapasitas lendutan balok beton bertulang bambu .

$\mathrm{HO}=$ tidak terdapat pengaruh yang signifikan terhadap antara penambahan jumlah tulangan terhadap kapasitas lendutan balok beton.

H1 = tidak terdapat pengaruh yang signifikan terhadap antara penambahan jumlah tulangan terhadap kapasitas lendutan balok beton.

Level of signifikan $(a)=5 \%=0,05$

Karena nilai Fhitung > Ftabel (6.66> 6,59 ), maka H0 di tolak. Sehingga terdapat pengaruh yang signifikan antara penambahan rasio tulangan bambu terhadap lendutan balok beton bertulang bambu.

\section{KESIMPULAN DAN SARAN}

\section{Kesimpulan}

Dari hasil analisis dan pembahasan maka dapat diperoleh kesimpulan penelitian sebagai berikut.

- Kapasitas beban maksimum beton bertulang bambu mengalami peningkatan dengan adanya penambahan rasio tulangan pada daerah tarik balok beton. Kapasitas balok beton bertulang bambu tulangan tarik 2D12 sebesar $4567 \mathrm{~kg}$, pada balok beton bertulang bambu tulangan tarik 3D12 sebesar $5517 \mathrm{~kg}$, pada balok beton bertulang bambu tulangan tarik 4D12 sebesar $6367 \mathrm{~kg}$, pada balok beton bertulang bambu tulangan tarik 5D12 sebesar $7342 \mathrm{~kg}$. Keruntuhan yang terjadi balok beton bertulang bambu adalah keruntuhan akibat lentur pada balok.

- Nilai lendutan menjadi berkurang dengan penambahan tulangan pada daerah tarik balok beton bertulang bambu, dengan beban yang sama $4567 \mathrm{~kg}$ untuk balok beton bertulang bambu tulangan tarik 2D12 nilai lendutan 18,2 mm, balok beton bertulang bambu tulangan tarik 3D12 nilai lendutan 11,6 mm, balok beton bertulang bambu tulangan tarik 4D12 nilai lendutan 10,3 mm, balok beton bertulang bambu tulangan tarik 5D12 nilai lendutan $8,6 \mathrm{~mm}$,
- Nilai beban maksimum balok beton bertulang bambu dengan tulangan daerah tarik 2D12 memiliki nilai beban maksimum sebesar $4567 \quad \mathrm{~kg}$ yang mencapai $56,61 \%$ dari nilai beban maksimun balok beton bertulang baja dengan tulangan daerah tarik 2D12 sebesar $8067 \mathrm{~kg}$.

\section{Saran}

Berdasarkan hasil yang diperoleh dalam penelitian ini, maka saran yang dapat diajukan adalah sebagai berikut :

- Menganalisis lebih detail tentang balok beton tulangan bambu dengan rajutan, terhadap balok beton tulangan bambu tampa rajutan .

- Mengadakan penelitian tentang modifikasi - modifikasi lainnya yang lebih efektif untuk mengatasi kelemahan bambu sebagai tulangan pada beton.

\section{DAFTAR PUSTAKA}

Anonim. 1977. Peraturan Beton Berutulang Indonesia 1971-N.I-2 (PBI 1971) Penerbitan Kelima.

ACI, 2005, Building Code Requerment For Structural Concrete, ( ACI-318-05) and Commentary ( ACI-R318-05), Farmington Hills, Michigan.

Akmaludin, Thomas C, 2006, Experimental Verification of an Effective Moment of Intertia Used in The Calculation of Reinforced Concrete Beam Deflection. UK Petra Surabaya, PP 89-98

Akmaluddim, Pathurahman 2012 Effective Moment Of Inertia Approach For Predection Deflection Of Concrete Beams Reinforced with Twisted Bamboo Cables

Dipohusodo, Istimawan. 1999. Struktur Beton Bertulang Berdasarkan SK SNI-T-151991-03 Departemen Umum. PT Gramedia Pustaka Utama: Jakarta.

Edward G. Nawy, P.E BETON BERTULANG Suatu Pendekatan Dasar ( ISBN 9793304- 47-2 )

Ghavami, 1995, Ultimate Load Behavior of bamboo reinforced lightweight Concrete Beams, Cement \& Concrete Composites, V 17. Pp 281-288 
Ghavami, K, 2005, Bamboo as Reinforcement in Structural Concret e Elements, Cement \& Concrete Composite, 27, pp 637-649.

Morisco. 1999. Rekayasa Bambu. Yogyakarta (ID) : Nafiri Offset 